\title{
Shell Shock: The Response of UK Neurology
}

\author{
Raphael D. Howard ${ }^{\text {a }}$ Robin S. Howard ${ }^{\text {b }}$

 \\ National Hospital for Neurology and Neurosurgery, London, UK
}

\section{Keywords}

Shell shock · Shock therapy · Faradism

\begin{abstract}
The neurological and psychological manifestations of trauma, confinement, and terror became apparent throughout Europe as soldiers were evacuated from the trenches of the Western Front. The response in the UK evolved as a result of the experience of medical staff embedded with the troops in base hospitals and the philosophy of those treating returned soldiers in specialist establishment. There were widely disparate approaches to the management encompassing simple supportive care, a psychanalytic approach and radical electric shock therapy. The latter was partially driven by the Queen Square experience in the UK but was also concurrently widely pursued throughout Europe. With experience, care was increasingly undertaken close to the front lines using a philosophy of immediacy and expectation of recovery. Postwar analysis was startlingly unsympathetic, yet the experiences and management of shell shock have guided psychiatric and medical understanding of functional illness and posttraumatic stress over the subsequent century. In this historical review, we have sought to present features of the UK response to the neurological manifestations of trauma, the way in which these changed as the war proceeded and the political and medical response in the aftermath of war.

(c) 2021 The Author(s).

Published by S. Karger AG, Basel
\end{abstract}

karger@karger.com www.karger.com/ene

Karger"
(C) 2021 The Author(s)

Published by S. Karger AG, Basel

This is an Open Access article licensed under the Creative Commons Attribution-NonCommercial-4.0 International License (CC BY-NC) (http://www.karger.com/Services/OpenAccessLicense), applicable to the online version of the article only. Usage and distribution for commercial purposes requires written permission.
In this historical review, we aimed to reflect the evolution of the UK response to the neurological and psychological trauma experienced by soldiers during the First World War. The philosophical and medical approach to the understanding of this trauma was driven by a dichotomy between respecting the needs of the individual soldier while reflecting the demands of maintaining the morale and efficiency of a fighting force.

The traumatic effects of war on soldiers had long been recognized and examples were to be found in the writings of Homer, Heroditus, Thucydides, and Josephus. The first experience of the traumatic effects of trench warfare came from the American Civil War (1861-1865) where 60,000 were killed, often in conditions unimaginable savagery and suffering. Silas Weir Mitchell (1829-1914) first recognized that symptoms including weight loss, fatigue, and exhaustion occurred among the combatants in the absence of a direct physical cause, naming the syndrome melancholia [1].

George Miller Beard [2] (1839-1883) first used the term neurasthenia in 1869 , defining it as "exhaustion of the nervous system due to civilization and the stresses of urbanisation without an organic lesion." The diagnosis was used to describe symptoms commonly seen among veterans of the Franco-Prussian War (1870) and the Boer War (1899-1902). By the beginning of the 20th century, symptoms were considered to resemble the nervous shock seen after a railway accident associated with the new steam trains and were therefore termed "Railway spine" [3].
Correspondence to:

Robin S. Howard, robinhoward@ nhs.net 
The conditions experienced by soldiers in the trenches of the Western front were unique. The use of mechanical warfare with high explosive and rapidly firing heavy artillery aimed at men restricted and with no route of escape meant that conditions were more destructive and oppressive than had ever been previously experienced. Following the Allied defeat at Mons and the first battle of Marne in 1914, the war became bogged down in static immobility. Soldiers in trenches for the first time experienced a sense of imprisonment, restriction, vulnerability, and immobilisation unerringly described by the World War I writers, on both sides of the conflict, including Edmund Blunden (1896-1974), Wilfred Owen (1893-1918), Robert Graves (18951985), Siegfried Sassoon (1886-1967), Ernst Jünger (1895-1997), and Erich Maria Remarque (1898-1970). High explosives were used for the first time and the effect of sustained gassing, shelling, and bombing led to a dreadful injury and mutilation. The factors contributing to the occurrence of shell shock have been reviewed in a number of books [4-8].

Within a few months of the outbreak of war, the first cases of disturbed soldiers were reported. There are accounts and photographs of silent, shuffling men tormented by nightmares and hallucinations, often paralysed, amnestic, or mute. Initially most were diagnosed as insane and sent back to civilian hospitals in Britain. Within months, there was an avalanche of cases arriving particularly at The Royal Victoria Hospital in Netley, near Southampton and No. 4 London General (King's College Hospital, Denmark Hill). Jones and Wessely [9] noted that the disorder was characterized by a range of physical symptoms, such as exhaustion, palpitations, shortness of breath, tremor, joint and muscle pain, dizziness and headache, together with nightmares, persistent anxiety, and difficulty in sleeping. By early 1915, there was an acute shortage of hospital beds leading to the requisition of many country "lunatic asylums," private medical institutions, spas and hotels for the treatment of war neurosis. The number of soldiers became a flood and the War office and military establishment became desperate to treat the soldiers and return them to the front as quickly as possible.

Turner [10] (1864-1945) was Consultant Physician to both the National Hospital and King's College Hospital. He made important contributions to the understanding of epilepsy and wrote an influential textbook of Neurology. At the age of 50, he was rushed by the War office to France in December 1914 when it became clear that "nervous and mental shock" casualties were

Shell Shock: The Response of UK Neurology burgeoning. He published a superb and meticulous description of the syndrome in the British Medical Journal) and recognized it as an acute stress disorder. His reports led the Army council to classify shell shock as a "wound" late in 1915 advocating rapid evacuation back to the UK [10].

Myers [11] (1873-1946) had pursued a distinguished academic career in physiology and experimental psychology before the war. At the outbreak of war, he was considered too old to enlist but, through persistence and patronage, he was able to secure a position as Assistant Physician to a privately established casualty hospital at Le Touquet. This was close to the frontline and also to Etaples which was the principle clearing station and hospital for the British Expeditionary Forces (BEF). He was therefore one of the first physicians to encounter soldiers evacuated from the front. He published 3 cases in the Lancet in February 1915 [11], introducing the term "shell shock." He first described symptoms developing in soldiers who had been caught in No Man's Land and subject to bombardment with multiple shells without direct injury. He concluded that the shattering noise caused by the explosion, which had showered the soldier with hot shards of metal, must have had a physical effect proposing that the physical force of a shell explosion was the origin of shell shock symptoms causing "an invisible fine molecular commotion in the brain" but nonetheless he noted "The close relation of these cases to those of "hysteria'."

Mott [12] (1853-1926) was able to observe one of the first groups of soldiers with shell shock evacuated to the UK in late 1914 as he oversaw the transition of the Maudsley Hospital in South London into a "Neurological Clearing Hospital." He hypothesized that the force of compression and decompression in turn, resulting from proximity to an explosion, led to microscopic brain haemorrhage, and he therefore categorized shell shock as a form of "commotio cerebri" [12, 13]. However, Mott [12] was based in his laboratory and had no first-hand experience of the trenches.

Myers [14, 15] soon realized that direct trauma could not be the correct explanation for the condition because men who had never been under fire experienced acute symptoms while others gradually developed psychological disturbances. This was immediately recognized by others but in the fast-moving times, the term "shell shock" spread like wildfire through the trenches. Its use was extended to include those who had not been in the vicinity of explosions but had witnessed ghastly sights and dreadful experiences. The affected soldiers initially manifest 
the same symptoms of tremor, nervousness and emotional liability with disturbed sleep, bad dreams, headache, and depression.

The deep divisions within the medical profession in the UK concerning the cause of "shell shock" led to a great deal of confusion regarding the diagnosis of the condition. Gradually, most military psychologists came to recognize that while physical injuries, such as concussion, could explain a handful of cases, the overwhelming majority of cases were associated with the emotional disturbance of trench warfare and the condition affected servicemen from all backgrounds [9].

By 1914, Gordon Holmes (1876-1965) was aged 38 and was director of research at Queen Square, he was also on the staff at 4 London Hospitals, and had published extensively $[16,17]$. He was appointed consultant neurologist to the British Army in France in early 1915 and served until soon after the Armistice. His medical role in the Army was critical, for it was neurologists who attended the "nervous patient" - not psychiatrists, who were generally confined to working in "asylums" with the psychotic patients. Holmes abhorred taking responsibility for psychological problems of warfare and rejected the possibility of a psychological explanation for physical symptoms. He sought the support and psychological expertise of Myers, who was then appointed consultant psychologist to the BEF, in overall charge of arrangements for shell-shocked men [18].

While public and medical opinion in Britain began to solidify against the practice of treating the shellshocked soldiers as either a malingerer or a coward or as "insane," the realization of the psychological origins of shell shock proved immensely embarrassing to the authorities as this was taken as an unfavourable reflection on the moral fortitude of the soldier. When Myers requested permission to publish the findings in 1916, he was told that the General Staff strongly opposed the broadcast of such ideas.

This hardening of military approach to the syndrome was reflected in the management of those suffering from the condition. In the early years of the war, very few French soldiers were sent home from the front but by contrast, in the UK, until the end of 1915, soldiers diagnosed with shell shock were shipped home to "Blighty" (the widely use slang term for the UK), from where it would take weeks or months to return to the front.

On 1st July 1916 at the Somme, there were 54,470 casualties in the UK army, including 19,000 dead, the biggest losses ever sustained by the army in 1 day. Between
July 1916 and November 1916, 419,600 British soldiers were killed or wounded $[7,9]$. It was estimated that there were 30,000 cases of shell shock. The military wish to maintain that shell shock was cowardice or lunacy was no longer tenable. Shell shock was a great leveller. All ranks were exposed to the extreme conditions that brought it on and both officers and men capitulated under the strain with large numbers of soldiers being admitted to Base Camp Hospital with severe and profound functional symptoms such as paralysis or loss of speech.

In response to these findings, Myers, Holmes, and others urged that all cases of shell shock be treated immediately and in close proximity to the front in France. Treatment in the forward area became widely accepted with the key principles of immediacy (treating as early as possible before chronic symptoms evolved), proximity (treatment near the front line and within earshot of battle), expectancy (positive expectancy of prompt cure by persuasive psychotherapy), simplicity of treatment (rest, sleep, and psychotherapy avoiding reference to civilian and childhood trauma), and centrality (organization to regulate flow and treatment of casualties) [19]. This form of treatment becomes recognized by the acronym of PIE [20]. In November 1916, 4 advanced units were established located about 10 miles from the trenches. "Shell shocked" men were transferred to a regimental aid post and thence to a casualty clearing station for classification and emergency attention. Finally, they were transferred to a base hospital a few miles behind the front line but they were not returned to the UK. Myers claimed there was a 31\% success rate in returning soldiers to the front as a result of this change in practice.

However, these base hospitals were profoundly distressing. Harvey Cushing wrote a harrowing account of the appalling hospital environment of the Neurosurgical Unit established by Holmes and Sargent at No 13 General Hospital in the old casino at Boulogne [21] describing 900 acutely ill soldiers with lice, maggot infestation, giant rats, and an overwhelming number of head and spinal wounds [21-23].

The practical difficulties were immense; the base at Boulogne became a refuge for many problems masquerading as "shell shock." For example, the diagnosis of shell shock gave the perfect excuse for malingerers who were fed up with war and wanted to go home, it became increasingly difficult to distinguish those genuinely affected from those malingering. Doctors found that they were expected to act as moral arbiters of a soldier's fitness to fight. The pressures on them were enormous because shell shock was not admissible as a plea in a court-martial 
for the crimes of cowardice or desertion for which the ultimate penalty was death. Therefore, as Myers remarked in his diaries: "from the military standpoint a deserter was either insane and destined for the madhouse or responsible and should be dead."

The acute management strategies for battle casualties during the Battle of Passchendaele (July-November 1917) were radically changed using the principles of PIE, including temporary respite from battle, sleep, food, and (relative) comfort followed by return to active duty and alcohol, freely used to combat fear. Evacuation was only contemplated after several weeks of treatment at a forward clearing station. These measures resulted in a dramatic reduction in the occurrence of shell shock.

In parallel with treatment close to the front, those soldiers evacuated back to the UK were dispersed throughout the country to a small number of treatment centres. Indeed, the management of shell shock came to dominate the military psychiatry during World War I.

At the Moss Side Military Hospital in Maghull, near Liverpool, a team established by Richard Rows focussed on the psychodynamics of environmental factors, believing terrifying events could trigger a traumatic neurosis in individuals with pre-existing vulnerabilities or repressed conflicts $[24,25]$. The clinician included Grafton Elliot Smith and T.H. Pear who proposed an anthropological explanation in which shell shock was seen as an organic illness which permitted behaviours proscribed by the Army discipline, including evacuation from the front line. The mission of the group was to use psychotherapy to analyse servicemen and return them back to the front. A report in the British Medical Journal described treatment in Maghull as: "embracing suggestion, persuasion, therapeutic conversion, re-education and exercise of the functionally paralysed limbs." The treatment of servicemen undertaken in Maghull was almost unique in showing sympathy and understanding towards the victim. Following the war, Maghull was described as the seedbed of British psychology. William HR Rivers (1864-1922) [26] was a neurologist and an anthropologist who was an early member of the staff at Maghull. He believed shell shock arose as a result of repressed traumatic memories and was best treated by abreaction and dream analysis. Rivers subsequently adopted similar techniques at Craiglockhart Military Hospital $[26,27]$ - and these underlay the discourses with the war poets Siegfried Sassoon and Wilfred Owen, following Sassoon's open letter denouncing the war [28] (Fig. 1).

The psychotherapeutic approach was entirely confined to soldiers who had returned to the UK. The Queen



Fig. 1. Siegfried Sassoon: letters to his uncle, Sir William Hamo Thornycroft, R.A., July 1917; published by permission from the Estate of George Sassoon, held by the British Library. (Shelfmark MS 56099).

Square case records suggest that "shell-shock" became an increasingly pejorative term as the condition was seen as a "contagious physical response of the weak." The records seem to indicate it was largely restricted to the lower ranks while officers were generally considered to have neurasthenia requiring a more gentle psychotherapeutic approach, occasionally involving transfer to specialist facilities [29]. The "rank and file" who were shipped back to the UK often received quite different treatment being subject to disciplinary therapy that emphasized the need for quick cure, if necessary, sometimes by notoriously practised at Queen Square by Yealland [30], a Canadian born neurologist when he was the Senior Resident [31]. This practise has been carefully described by Linden, Jones, and Wessely $[6,32,33]$. Although he never became a consultant at Queen Square, it is clear that Yealland's approach was strongly supported by many neurologists both there and elsewhere. He used a technique of "Faradization" which involves the application of electric shocks. While originally developed specifically to cure symptoms, such as paralysis or sensory loss, the electric shock treatment was also deemed successful for identifying ma- 
lingerers from genuine patients. The population received by Queen Square was atypical and selected. They often saw the most recalcitrant cases of hysteria. Yealland gained a high reputation as a "miracle worker" because he was able to send a man back to the front within days of seeing him. In truth, all his treatment did was removing the hysterical symptoms; it did little to treat the cause. He claimed a success rate of almost $100 \%$ but nobody kept a record of longer term outcome.

Others neurologists in the UK were advocating the use of electrical stimulation. Major (later Sir) Arthur Hurst used film to document the apparent dramatic recovery of many patients with movement disorders that were thought to be intractable, following a variety of treatment modalities, including occupational therapy $[34,35]$. The film that he made was deeply flawed with many of the apparent recoveries being re-enacted for the cameras. Similarly, Mott himself treated servicemen with electric shocks and was eager to describe the benefits in reinforcing persuasion, suggestion, and re-education. As with Yealland, there was an absence of follow-up or corroboration in subsequent war pension files [34].

A similar dichotomy existed in the German approach to shell shock. Hermann Oppenheim and his school had suggested that "traumatic neurosis" had an organic basis due to microscopic lesions in the brain and nervous system. His views were influential in the UK but fell out of favour as the neuropsychological basis of shell shock was is increasingly recognized by neurologists, including Max Nonne $[6,36]$. The German use of the electric shock method accompanied by the power of auto-suggestion (using shocks given haphazardly in a specially decorated mediaeval Gothic room, as propounded by Dr. Fritz Kaufmann) was contemporaneous with Yealland in the UK [37].

In Austria, there was a more widespread development of electrical therapy. After the war, particular ethical concerns were raised about the work of Austrian Nobel Prize winner Julius Wagner-Jauregg, the only psychiatrist to win the Nobel Prize, in the 1920s. Although it was reported that patients had died from an overdose of electricity, he was subsequently exonerated by an enquiry led by Freud.

In France, Babinski had rejected Charcot's notion of traumatic hysteria and considered war neurosis to be entirely due to malingering. Both Clovis Vincent and Gustave Roussy introduced techniques of faradic and galvanic electrical stimulation after 1915 which became known as "torpillage" and consisted of " the brusque application of galvanic currents, strong enough to be extremely painful, in hysterical conditions, and the continuance of the procedure to the point at which the deaf hear and the dumb speak" [38-40]. The techniques of electric shock therapy were undertaken with increasing brutality and coercion until, by the end of the war, it became difficulty to distinguishing when shock therapy emerged from a treatment to a punishment.

For many repatriated servicemen, perhaps not surprisingly, war neuroses continue to be a serious problem after their return to civilian life. In the UK, the flood of disabled soldiers with pension needs was devastating for the postwar economy. Approximately 110,000 men applied for pensions for shell shock-related disorders in the decade following 1919 costing the government more than GBP $£ 10$ million per year. The political effects of these claims led directly to be institution of the Southborough commission in 1922 [41]. Furthermore, public concern arose because it became increasingly clear that soldiers accused of cowardice and desertion and "shot at dawn" were often suffering from shell shock, depression, or mania.

Sir Gordon Holmes gave evidence that was striking in its clarity and characteristics in its lack of sentiment and sympathy. He stated that, after the Somme, large numbers of soldiers were admitted to base camp hospital with gross hysterical symptoms, such as paralysis or loss of speech resulting from a decline in morale and training. He considered many believed that if they had shell shock they would escape further service in the line for the time being and the incidence was particularly high among fresh troops or short training and low morale and also in older men. He believed encouragement and support were usually adequate but if not, the Medical Officer should treat with "the appropriate method." In many cases, he suggested that the quickest method was to tell the patient we should give him electricity to help him along and almost invariably he got his speech back within half an hour. Similarly, Major WJ Adie believed the development of shell shock was related to low morale and favoured the "Queen Square method." Rivers was perhaps more considered in recognizing the distinction between men who broke down soon after going to the front because they were not fitted for the position in which they found themselves and officers who broke down after long and continued strain, often associated with relatively minor battle trauma. Myers himself felt completely unable to contribute to the enquiry because of the traumatic effects of the events he had witnessed.

The findings of the committee were predictably emollient. They made no reference to the use of electricity or faradism and avoided attributing a psychological basis to 




Fig. 2. The "Shot at Dawn" Memorial monument at the National Memorial Arboretum near Alrewas, Staffordshire, UK, commemorating the 309 British Army and Commonwealth soldiers executed after courts-martial for desertion and other capital offences during World War I (Shot at Dawn. World War I Centenary (ox. ac.uk) By Noisette [CC BY-SA 3.0]).

the condition. The conclusions were clearly influenced by the enormous demand for social and economic support, particularly during the depression years that followed the war. Many victims returned to families and found themselves forgotten or without work and without any support for those who had undoubtedly suffered the long-term effects of battle trauma.

The findings of the Southborough Enquiry still echo as a startling betrayal of the combatants and a deeply graphic portrayal of the "futility of war." The figures in this story continue to resonate with us in the UK, 100 years later - Myers, Rivers, Sassoon, Owen, and Graves but, most of all, in an obligation for us as physicians to reflect upon those "shot at dawn" for cowardice [42, 43] (Fig. 2).

\section{Acknowledgments}

The authors are grateful to the library and archive staff at The National Hospital and, in particular, Sarah Lawson and the late Louise Shepherd.

\section{Conflict of Interest Statement}

There are no conflicting interests to declare.

\section{Funding Sources}

The authors received no external funding.

\section{Author Contributions}

Raphael D. Howard contributed to the research and writing of the manuscript. Robin S. Howard contributed to the research and writing of the manuscript.

\section{References}

1 Boller F, Birnbaum D. Silas Weir Mitchell: neurologists and neurology during the American civil war. Front Neurol Neurosci. 2016 38:93-106.

2 Goetz CG. Poor Beard!! Charcot's internationalization of neurasthenia, the "American disease”. Neurology. 2001;57:510-4.

3 Harrington R. On the tracks of trauma: railway spine reconsidered. Soc Hist Med. 2003; 16:209-23.

4 Holden W. Shell Shock. London: Channel 4 books; 1998. p. 7-71.

5 Lees P. Shell shock: traumatic neurosis and the British soldiers of the first world war. Basingstoke: Palgrave, Macmillan; 2002.

6 Linden S. They called it shell shock (combat stress in the first world war). Solihull: Helion \& Company Limited; 2016.
7 Jones E, Wessely S. Shell shock to PTSD. Hove \& New York: Pub. Psychology Press, Taylor \& Francis Group; 2005. p. 1-48.

8 Shephard B. A war of nerves. Soldiers and psychiatrists 1914-1994. London: Pimlico; 2002. p. 97-109.

9 Jones E, Wessely S. Battle for the mind: world war 1 and the birth of military psychiatry. Lancet. 2014;384:1708-14.

10 Turner WA. The Bradshaw lecture on neuroses and psychoses of war. Lancet. 1918; 192(4967):613-8.

11 Myers C. A contribution to the Study of Shell Shock. Lancet. 1915;185(4772):316-20.

12 Mott FW. The Chadwick lecture on mental hygiene and shell shock during and after the war. Br Med J. 1917;2:39-42.
13 Jones E. "An atmosphere of cure": Frederick Mott, shell shock and the Maudsley. Hist Psychiatry. 2014;25(4):412-21.

14 Myers CS. A final contribution the study of Shell Shock.1 being a consideration of unsettled points needing investigation. Lancet. 1919;193(4976):51-4.

15 Myers CS. Shell shock in France 1914-18. Cambridge: Cambridge at the University Press; 1940.

16 McDonald Critchley M. The divine banquet of the brain. Gordon Holmes: the man and the neurologist. New York: Raven Press; 1979. p. 229-34.

17 McDonald I. Gordon Holmes lecture: Gordon Holmes and the neurological heritage. Brain. 2007 Jan;130(Pt 1):288-98.

18 Macleod AD. Shell shock, Gordon Holmes and the great war. J R Soc Med. 2004;97:86-9. 
19 Crocq MA, Crocq L. From shell shock and war neurosis to posttraumatic stress disorder: a history of psychotraumatology. Dialogues Clin Neurosci. 2000;2(1):47-55.

20 Artiss KL. Human behaviour under stress: from combat to social psychiatry. Mil Med. 1963; 128:1011-5.

21 Lepore FE. Harvey Cushing, Gordon Holmes, and the neurological lessons of world war I. Arch Neurol. 1994;51:711-22.

22 Cushing H. From a surgeon's journal 19151918. London: Constable; 1936.

23 Carey ME. Major Harvey Cushing's difficulties with the British and American armies during world war I. J Neurosurg. 2014;121(2): $319-27$.

24 Jones E. Shellshock at Maghull and the Maudsley: models of psychological medicine in the UK. J Hist Med Allied Sci. 2010;65(3):368-95.

25 Forrester J. 1919: psychology and psychoanalysis, Cambridge and London - Myers, Jones and MacCurdy. Psychoanal Hist. 2008; 10(1) 37-94.

26 Slobodin R. W.H.R. Rivers. Stroud: Sutton Publishing Limited; 1997. p. 55-65.

27 Rivers WHR. An address on the repression of war experience. Lancet. 1918;191(4927):1737.
28 Loughran T. "Shell-Shock" from the first world war digital archive. London: The British Library; 2018. Available from: https:// www.bl.uk/world-war-one/articles/shellshock.

29 Howard RD, Howard RS. FM2-5 Shell shock or neurasthenia? The Queen Square experience in the first world war. J Neurol Neurosurgery and Psychiatry. 2019;90(3):FM2-5.

30 Yealland LR. Hysterical disorders of warfare. London: McMillan; 1918.

31 Adrian ED, Yealland LR. The treatment of some common war neuroses. Lancet. 1917; 189(4893):867-72.

32 Linden SC, Jones E, Lees AJ. Shell shock at Queen Square: Lewis Yealland 100 years on. Brain. 2013 Jun;136(Pt 6):1976-88.

33 Linden SC, Jones E. Shell Shock' revisited: an examination of the case records of the National Hospital in London. Med Hist. 2014;58(4): 519-54.

34 Jones E. War neuroses and Arthur Hurst: a pioneering medical film about the treatment of psychiatric battle casualties. J Hist Med Allied Sci. 2012 Jul;67(3):345-73.

35 Moscovich M, Estupinan D, Qureshi M, Okun MS. Shell shock: psychogenic gait and other movement disorders - a film review. Tremor Other Hyperkinet Mov. 2013;3:tre03-110-774-2.
36 Holdorff B. The fight for "traumatic neurosis," 1889-1916: Herman Oppenheim and his opponents in Berlin. Hist Psychiatry. 2011; 22(4):465-76.

37 Linden SC, Jones E. German battle casualties: the treatment of functional somatic disorders during world war I. J Hist Med Allied Sci. 2012;68(4):627-58

38 Bogousslavsky J, Tatu L. French neuropsychiatry in the Great War: between moral support and electricity. J Hist Neurosci. 2013;22(2): $144-54$.

39 Tatu L, Bogousslavsky J, Moulin T, Chopard JL. The "torpillage" neurologists of World War I: electric therapy to send hysterics back to the front. Neurology. 2010;75:279-83.

40 Tatu L, Bogousslavsky J. World War 1 psychoneurosis: hysteria goes to war. Front Neurol. Neurosci. 2014;35:157-68.

41 Great Britain War Office Committee. Report of the war office committee of enquiry into "shell-shock". London: London Imperial War Museum; 2014. (First published in 1922).

42 Corns C, Hughes-Wilson J. Blindfolded and alone (British Military Executions in the Great War). London: Cassell, Clays, St. Ives; 2005. p. 176-223.

43 Wessely S. The life and death of private Harry Farr. J R Soc Med. 2006;99:440-3. 